\title{
Exposure of Estrus Female and its Urine Improves Semen Quality Profiles and Freezabilityin Mithun
}

\author{
P. Perumal*
}

ICAR-National Research Centre on Mithun, Medziphema, Nagaland (797 106), India

\author{
Corresponding Author \\ P. Perumal \\ e-mail: perumalponraj@gmail.com
}

\author{
Article History \\ Article ID: AR1926c \\ Received in $06^{\text {th }}$ November, 2018 \\ Received in revised form $07^{\text {th }}$ December, 2018 \\ Accepted in final form $10^{\text {th }}$ December, 2018
}

\begin{abstract}
Effect of different methods of biostimulation on semen quality profiles (SQPs) and freezability and endocrinological profiles in mithun bulls was studied. Twelve adult healthy mithun bulls (4 to 5 years) with good body condition (score 5-6)were selected from mithun breeding farm, ICAR-NRC on Mithun, Medziphema, Nagaland, India. Biostimulation methods were categorised into four groups and each group consisted of three animals, viz. Gr I: exposure of non-estrus female, Gr II: exposure of urine of non-estrus female, Gr III:exposure of urine of estrus female and Gr IV: exposure of estrus female. These bulls were bio-stimulated once in 5 days for two months (total 12 visits) of the respective group. Semen samples were collected after 12 visits and before collection, the female or its urine is exposed to bulls in every time. A total of 40 semen samples ( 10 from each group) were collected by transrectal massage method and SQPs, velocity and motility parameters were measured. Blood samples were collected immediately after exposure and hormone profiles such as follicle stimulating hormone (FSH), luteinizing hormone (LH) and testosterone were analysed by using commercial diagnostic kits. Result revealed that significant $(p<0.05)$ difference was observed among the methods of biostimulationfor all theexperimental parameters. Of which, highest value was observed in bulls exposed to estrus female or its urine than non-estrusfemales or its urine. Therefore, it was concluded that exposure of estrus cows or its secretions have capability to increase the semen production and the sperm has higher freezability in mithun.
\end{abstract}

Keywords: Biostimulation, hormones, estrus female, semen, freezability

\section{Introduction}

Mithun (Bos frontalis) is a domesticated unique and rare bovine species available in NEH region of India and reared in free-range extensive or semi-intensive system. Mithunis considered as an important livestock in socio-economiccultural-religious life of the mithun rearing tribals in the $\mathrm{NEH}$ region. Natural breeding practice is followed in this unique beautiful bovine species with various demerits such as intensive increasing of inbreeding depression, genital disease transmission, increasing of production and reproduction cost, decreasing the production and reproduction potential of mithun, increasing crossbred population with other bovine species, various reproductive and fertility disorders, etc. are severely encountered in mithunin its rearing states. Mithun is considered as not yet endangered bovine species but are severely suffering from non-cyclical population fluctuations on a regional basis as per the livestock censuses of Government of India due to various factors such as lack of proper breeding, feeding, disease management and breeding bulls. Therefore, various sectors including the government, social, public and mithungrowers need to take appropriate policies and programmes to conserve the mithun germplasm in their pure form in their original territory. There are various factors such as collection method (Bhattacharyya et al., 2009), vaccination (Perumal et al., 2013), season (Perumal et al., 2015; Perumal et al., 2017), breed (Rajoriya et al., 2013), patho-physiological conditions (Perumal et al., 2016), testicular biometry (Perumal and Rajkhowa, 2013), etc. are significantly affect the spermatogenesis, its freezability and fertility. It was observed that mithun female expresses her heat as a silent estrus, and mucus discharge from the vulva and standing to be mounted by mithun bulls were observed occasionally. Detection of estrous in mithun cows through visual observations is difficult, and bellowing is generally not occurred in mithun during estrus. Further in general, the mithun bull is shy in nature and does not mount the cows that are in estrous (heat). Earlier study in mithun, it was reported that semen ejaculates were collected by using the fresh or refrigerated estruscow urine (Mondal et al., 2010). However, there were reports oneffect of different methods of biostimulationon the sexual behaviour or libido and ejaculation in different livestock species, lacking in mithun species. Biostimulationis due to presence of bio-molecules in the secretion of external body fluids. These bio-chemical molecules or signals are highly 
species-specific, for example, copulinin the rhesus monkey (Michael, 1973), frontalin in Asian elephants (Rasmussen and Greenwood, 2003) and valeric acid or a mixture of fatty acids in oestrous felids (Bland, 1979). Based on available literature and to the best of our knowledge, this is the first report on effect of biostimulation on semen production and its quality profiles in mithun. Therefore, the present study was designed to assess the effect of different methods of biostimulation on semen production and freezability of adult breeding mithun bulls to select the suitable method/(s) for semen collection for artificial breeding programme in this rare precious bovine species.

\section{Materials and Methods}

\subsection{Experimental animals}

Twelve numbers $(n=12)$ of healthy adult mithun bulls of 4-6 yr of age were selected from the herd, mithun breeding farm, ICAR-NRC on Mithun, Medziphema, Nagaland, India and the experimental station is located between $25^{\circ} 54^{\prime \prime} 30^{\prime \prime}$ North latitude and $93^{\circ} 44^{\prime} 15^{\prime \prime}$ East longitude and at an altitude range of 250-300 meter above MSL. The average body weight of the bulls at $4 \mathrm{yr}$ of age was $505 \mathrm{~kg}$ (495 to $510 \mathrm{~kg}$ ), which was increased at $6 \mathrm{yr}$ of age to $530 \mathrm{~kg}$ (520 to $540 \mathrm{~kg}$ ) with good body condition (score 5-6), maintained under uniform feeding, housing, lighting and other managemental practices with daily offered ad libitum drinking water.

\subsection{Experimental groups}

Biostimulation methods were categorised into four groups and each group consisted of three animals, viz. Gr I: exposure of non-estrus female, Gr II: exposure of urine of non-estrus female, Gr III: exposure of urine of estrus female and Gr IV: exposure of estrus female. The experiments were conducted in an isolated shed with proper precautions. These bulls were bio-stimulated once in 5 days for two months (total 12 visits) of the respective group. Semen samples were collected after 12 visits and before collection, the female or its urine is exposed to bulls in every time. A total of 40 semen samples ( 10 semen samples from each group) were collected by transrectal massage method and SQPs, velocity andmotility parameters and in-vitro zona binding assay profiles were measured. The status of estrus of cows was identified by different behavioural and physical signs of estrus (van Eerdenburg et al., 1996) and per rectal examination was conducted to find out the status of heat of the animals that were expressed one or more symptoms or signs of heat. Bull parading was implemented in every day morning as well as in evening to find out the estrus animals. Cows with intensive estrus were selected, separated and isolated to collect the urine and urine was collected after stimulation of the perineum and preserved in deep freezer at $-80{ }^{\circ} \mathrm{C}$ as different small quantities, used for the experiment. The collected estrus cow urine was sprinkled over the perineal region of mithun cows that were not in estrusand the urine was sprayed over the nose and mouth of the bulls and these bulls were allowed to mount or react with the cow and semen ejaculates were collected. Similarly urine from the non-estrus female was collected, preserved and utilized in the experiment. The complete experiment was conducted in the completely isolated and confined animal house with proper precautions. The experimental shed was isolated and kept away from the main animal sheds. The experimental bulls were not exposed to any animals or their movement in and on around the experimental shed. The bulls were placed and treated separately in the individual shed with no contact of each other bulls in the experiment. All the experimental animals were treated or tested in uniform method with same animal attendant and changing of clothes of animal attendant was mandatory before entering into each room during the whole experimental period.

\subsection{Semen collection and analysis}

Semen samples were collected twice a week by transrectal massage method from the mithun bulls. Briefly, seminal vesicles were massaged centrally and backwardly for 5 min followed by the gentle milking of ampullae one by one for 3-5 min, which resulted into penile erection and semen ejaculation. Initial watery and transparent seminal secretions were thrown out and fresh good quality semen samples were collected in measurement test tube by using a good quality funnel. The andrological parameters such as success rate (number of animal responded to number of animals attempted), protrusion time (time from start of massage to time of protrusion), ejaculation time (time from protrusion to ejaculation) and length of penis at the time of ejaculation were evaluated. Immediately after collection, the samples were preserved at $37^{\circ} \mathrm{C}$ in a water bath and evaluated the routine SQPs such as volume, colour, consistency, concentration, mass activity and $\mathrm{pH}$. After discarding the ejaculates with wide variation in $\mathrm{pH}$, colour or too low volume $(<0.5 \mathrm{ml})$, rest were evaluated microscopically. These ejaculates were evaluated and accepted for evaluation if the following criteria were met: concentration: $>500$ million $\mathrm{ml}^{-1}$, mass activity $>2.5+$, individual motility: $>70 \%$, and total morphological abnormalities: $<15 \%$. Following the above-screening protocol, 80 of 120 ejaculates were selected. With an average of 10 ejaculates were collected from each bull. After the preliminary evaluations, two consecutive ejaculates of a same bull were pooled together (termed "sample" hereafter, $n=40 ; 10$ each for four experimental groups) and subjected to the twofold initial dilution with pre-warmed $\left(37^{\circ} \mathrm{C}\right)$ Tris-citrate-glycerol (TCG) extender. The partially diluted samples were then brought to the laboratory in an insulated flask containing warm water $\left(37^{\circ} \mathrm{C}\right)$ for further processing. Each sample was diluted (to get final concentration of 60 million spermatozoa $\mathrm{ml}^{-1}$ ) with the TCG extender. Diluted semen samples were cooled from 37 to $5{ }^{\circ} \mathrm{C}$ in a cold cabinet (IMV, France) and maintained at $5{ }^{\circ} \mathrm{C}$ for $2 \mathrm{~h}$. Polyvinyl chloride (PVC) straws $(0.5 \mathrm{ml})$ (IMV, France) were filled and maintained in a cold cabinet at $5{ }^{\circ} \mathrm{C}$ for $2.5 \mathrm{~h}$. Subsequently, these straws were cleaned, dried and spread over the freezing rack. The rack 
along with straws were kept in biological freezer for freezing and then these straws were plunged into the liquid nitrogen $\left(-196^{\circ} \mathrm{C}\right)$ and stored. The stored semen straws were thawed at $37^{\circ} \mathrm{C}$ for $30 \mathrm{~s}$. The percentage of sperm motility (Nikon, Eclipse 80i; magnification $400 \times$ with thermostage maintained at $37^{\circ} \mathrm{C}$; Salisbury et al., 1985), Sperm motility and velocity parameters by computer assisted sperm analyser (CASA; Perumal et al., 2016), viability and total sperm abnormality by Eosin-Nigrosin staining (Lasley and Bogart, 1944; Tomar, 1997), acrosomal integrity by Giemsa staining (Watson, 1975), intactness of plasma membrane by hypo-osmotic swelling test (HOST) (Jeyendran et al., 1984), nuclear abnormality by Feulgen's staining technique (Barth and Oko, 1989) and vanguard distance travelled by sperm in the bovine cervical mucus (Matousek et et al., 1989; Prasad et al., 1999) were determined as per standard procedure. Along with above mentioned semen quality parameters, mitochondrial membrane potential by JC- 1 stain were determined in post thawed semen samples (Perumal et al., 2011).

\subsection{Hormone analysis}

The blood samples were collected by venipuncture of jugular vein in heparin tubes (20 IU of heparin $\mathrm{ml}^{-1}$ of blood) from the experimental mithun bulls $15-30$ minutes after exposure to the female cows or its urine for estimation of testosterone, FSH and LH. The blood samples were centrifuged at 1200x $\mathrm{g}$ for $15 \mathrm{~min}$ at $4{ }^{\circ} \mathrm{C}$. The plasma samples were separated rapidly, labelled properly and preserved at $-80^{\circ} \mathrm{C}$ in deep freezer for further estimation of testosterone, FSH and $\mathrm{LH}$ with commercial available diagnostic kits (RIA and ELISA kits). Follicle stimulating hormone (analytical sensitivity: 0.1 $\mathrm{mlUml}^{-1}$; intra- and inter-assay coefficients of variation: 6.47 and $9.54 \%$, respectively) and luteinizing hormone (analytical sensitivity: $13 \mathrm{nmol} \mathrm{I}^{-1}$; intra- and inter-assay coefficients of variation: 5.15 and $8.31 \%$, respectively) were estimated with commercially available bovine ELISA kits (MBS033405, MBS9346806, My Biosource, San Diego, CA, USA, respectively) by optical density $(\lambda 450 \mathrm{~nm})$ in 96-well clear polypropylene microplate using a MRC Microplate Reader (UT-2100C, Israel). Testosterone (analytical sensitivity: $0.02 \mathrm{ng} \mathrm{ml}^{-1}$; intra-and inter-assay coefficients of variation: 5.13 and $9.27 \%$, respectively) was estimated by RIA based diagnostic kits (Immunotech, France) by using a gamma counter (PC-RIA MAS; Stretec, Germany).

\subsection{Statistical analysis}

The statistical analysis of the data was performed as per standard procedures (Snedecor and Cochran, 1994). The results were analysed statistically and expressed as the mean \pm SEM. Means were analyzed by one way analysis of variance (ANOVA), followed by the Tukey's post hoc test to determine the significant differences between the four experimental groups on SQPs, CASA parametersand endocrinological profiles using the SPSS/PC computer program (version 15.0; SPSS, Chicago, IL). Tables present the non-transformed data. The data used in the study were tested for normality before analysis using Shapiro Wilk statistics. Differences with values of $p<0.05$ were considered to be statistically significant after arcsine transformation of percentage data by using SPSS 15.

\section{Results and Discussion}

Andrological parameters (Table 1), semen production andits quality profiles at fresh (Table 2) and post thaw (Table 4),

Table 1: Comparison of andrological profiles following exposure of estrus cows and its urine in mithun (Mean \pm SEM)

\begin{tabular}{lcccc}
\hline Andrological Parameters & Group I & Group II & Group III & Group IV \\
\hline Success rate (\%) & 75.00 & 76.00 & 85.00 & 87.00 \\
Protrusion time (sec) & $172.81 \pm 2.42^{\mathrm{b}}$ & $178.34 \pm 3.33^{\mathrm{b}}$ & $104.71 \pm 2.32^{\mathrm{a}}$ & $99.87 \pm 1.78^{\mathrm{a}}$ \\
Ejaculation time (sec) & $247.89 \pm 2.56^{\mathrm{b}}$ & $256.68 \pm 2.31^{\mathrm{b}}$ & $165.68 \pm 2.85^{\mathrm{a}}$ & $154.58 \pm 2.14^{\mathrm{a}}$ \\
Length of penis (inch) & $8.28 \pm 1.32^{\mathrm{b}}$ & $8.16 \pm 1.17^{\mathrm{b}}$ & $10.89 \pm 1.32^{\mathrm{a}}$ & $11.78 \pm 0.78^{\mathrm{a}}$ \\
\hline
\end{tabular}

Means with different superscripts within rows differ significantly ( $p<0.05)$; $\mathrm{Gr}$ I: Exposure of non-estrus female; Gr II: Exposure of urine of non-estrus female; Gr III: Exposure of urine of estrus female; Gr IV: Exposure of estrus female

CASA parameters at fresh (Table 3 ) and post thaw stage (Table 5 ) in the present study revealed a significant $(p<0.05)$ difference among the methods of biostimulation. Andrological parameters such as length of penis and success rate were significantly $(p<0.05)$ higher whereas protrusion time and ejaculation time were significantly $(p<0.05)$ lower in group of bulls exposed to estrus cows and its urine than in group of bulls exposed to non-estrus or its urine. Semen quality profiles such as volume, concentration, mass activity, motility (total motility, motility and velocity measured by CASA), viability, acrosomal integrity, intactness of plasma membrane and nuclear membrane, vanguard distance travelled by sperm in estrousbovine cervical mucus were significantly $(p<0.05)$ higher whereas total sperm abnormality was significantly lower $(p<0.05)$ in adult mithun bulls that were exposed to estrus female group than in bulls exposed to nonestrusfemaleand its urine in fresh and post thawed semen accordingly. Endocrinological profiles revealed testosterone, FSH and LH were significantly $(p<0.05)$ higher in bulls got exposure of estrus females or its urine than non-estrus cows or its urine (Table 6). Based on the results obtained in the present study, it was clearly indicated that the exposure of estrus females or its urine has not only improved endocrinological profiles, semen quality parameters but also enhanced the 


\begin{tabular}{|c|c|c|c|c|}
\hline Seminal quality parameters & Group I & Group II & Group III & Group IV \\
\hline Volume $(\mathrm{ml})$ & $1.60 \pm 0.17^{b}$ & $1.68 \pm 0.29 \mathrm{~b}$ & $2.76 \pm 0.27^{a}$ & $3.35 \pm 0.12^{\mathrm{a}}$ \\
\hline Colour & Milky watery & Watery to medium & Creamy white & Creamy white \\
\hline Concentration $\left(\times 10^{6} \mathrm{ml}^{-1}\right)$ & $537.12 \pm 4.23^{b}$ & $541.78 \pm 3.61^{\mathrm{b}}$ & $615.67 \pm 3.56^{a}$ & $639.14 \pm 4.49^{a}$ \\
\hline Mass activity (grade) & $2.56 \pm 0.58^{b}$ & $2.57 \pm 0.46^{b}$ & $3.28 \pm 0.16^{\mathrm{a}}$ & $3.62 \pm 0.21^{\mathrm{a}}$ \\
\hline Individual motility (\%) & $73.23 \pm 3.02^{\mathrm{b}}$ & $71.29 \pm 1.25^{\mathrm{b}}$ & $80.72 \pm 3.14^{a}$ & $83.46 \pm 2.17^{a}$ \\
\hline Livability (\%) & $74.32 \pm 2.67^{b}$ & $73.34 \pm 1.73^{b}$ & $82.12 \pm 3.12^{\mathrm{a}}$ & $84.65 \pm 1.81^{\mathrm{a}}$ \\
\hline Acrosomal integrity (\%) & $73.55 \pm 2.32^{\mathrm{b}}$ & $72.82 \pm 1.94^{\mathrm{b}}$ & $85.54 \pm 2.86^{a}$ & $86.75 \pm 2.43^{a}$ \\
\hline Total sperm abnormality (\%) & $14.65 \pm 1.12^{\mathrm{b}}$ & $14.23 \pm 1.65^{b}$ & $7.32 \pm 1.06^{\mathrm{a}}$ & $7.11 \pm 1.12^{\mathrm{a}}$ \\
\hline Plasma membrane integrity (\%) & $74.39 \pm 2.78^{b}$ & $75.45 \pm 1.87^{b}$ & $85.92 \pm 3.32^{\mathrm{a}}$ & $86.78 \pm 2.51^{\mathrm{a}}$ \\
\hline Nuclear integrity (\%) & $75.44 \pm 2.12^{\mathrm{b}}$ & $76.21 \pm 1.78^{b}$ & $86.75 \pm 2.95^{\mathrm{a}}$ & $87.78 \pm 2.31^{\mathrm{a}}$ \\
\hline $\mathrm{CMPT}\left(\mathrm{mm} \mathrm{h}^{-1}\right)$ & $17.87 \pm 1.21^{c}$ & $18.12 \pm 1.18^{c}$ & $22.31 \pm 1.12^{b}$ & $25.43 \pm 1.87^{\mathrm{a}}$ \\
\hline $\mathrm{pH}$ & $7.12 \pm 0.04^{b}$ & $7.16 \pm 0.05^{b}$ & $6.80 \pm 0.03^{a}$ & $6.76 \pm 0.06^{a}$ \\
\hline
\end{tabular}

Means with different superscripts within rows differ significantly ( $p<0.05)$; Gr I: Exposure of non-estrus female; Gr II: Exposure of urine of non-estrus female; Gr III: Exposure of urine of estrus female; Gr IV: Exposure of estrus female; CPMT: Cervical mucus penetration test; vanguard distance travelled by sperm in estrus mucus

Table 3: Comparison of motility and velocity profiles measured by computer assisted sperm analyser (CASA) of fresh semen following exposure of estrus cows and its urine in mithun(Mean \pm SEM)

\begin{tabular}{|c|c|c|c|c|}
\hline CASA Parameters & Group I & Group II & Group III & Group IV \\
\hline Forward progressive motility (\%) & $34.76 \pm 1.21^{\mathrm{b}}$ & $36.21 \pm 1.35^{b}$ & $58.89 \pm 2.75^{a}$ & $60.12 \pm 1.25^{\mathrm{a}}$ \\
\hline Total motility (\%) & $54.64 \pm 1.56^{\mathrm{b}}$ & $56.43 \pm 1.36^{b}$ & $76.25 \pm 1.18^{\mathrm{a}}$ & $79.56 \pm 1.21^{\mathrm{a}}$ \\
\hline Static sperms (\%) & $43.21 \pm 1.98^{b}$ & $42.64 \pm 2.34^{\mathrm{b}}$ & $23.76 \pm 1.43^{\mathrm{a}}$ & $22.45 \pm 1.34^{a}$ \\
\hline Curvilinear velocity (VCL) $\left(\mu \mathrm{m} \mathrm{sec}{ }^{-1}\right)$ & $127.67 \pm 2.76^{b}$ & $136.85 \pm 2.51^{b}$ & $189.57 \pm 3.47^{\mathrm{a}}$ & $187.33 \pm 4.28^{a}$ \\
\hline Straight line velocity (VSL) $(\mu \mathrm{m} \mathrm{sec}-1)$ & $58.44 \pm 1.65^{b}$ & $60.78 \pm 1.67^{b}$ & $89.86 \pm 1.50^{a}$ & $89.45 \pm 2.68^{a}$ \\
\hline Average path velocity (VAP) $\left(\mu \mathrm{m} \mathrm{sec}{ }^{-1}\right)$ & $87.23 \pm 1.51^{\mathrm{b}}$ & $88.41 \pm 1.23^{b}$ & $118.63 \pm 2.84^{\mathrm{a}}$ & $115.74 \pm 2.56^{\mathrm{a}}$ \\
\hline Linearity (LIN) (\%) & $40.32 \pm 1.65^{b}$ & $41.76 \pm 1.67^{b}$ & $47.61 \pm 1.65^{\mathrm{a}}$ & $48.23 \pm 0.96^{a}$ \\
\hline Straightness (STR) (\%) & $65.87 \pm 1.73^{b}$ & $67.54 \pm 1.25^{b}$ & $77.76 \pm 1.36^{\mathrm{a}}$ & $78.28 \pm 1.67^{a}$ \\
\hline Wobble (WOB) (\%) & $67.33 \pm 1.64^{b}$ & $65.33 \pm 1.69^{b}$ & $62.83 \pm 1.56^{a}$ & $61.50 \pm 1.32^{\mathrm{a}}$ \\
\hline Amplitude of lateral head displacement $(\mu \mathrm{m})$ & $4.48 \pm 1.12^{b}$ & $5.28 \pm 0.98^{b}$ & $8.76 \pm 1.21^{\mathrm{a}}$ & $8.75 \pm 1.22^{\mathrm{a}}$ \\
\hline Beat/cross frequency (BCF) (Hz) & $21.21 \pm 1.34^{b}$ & $22.67 \pm 1.69^{b}$ & $28.34 \pm 1.65^{a}$ & $28.42 \pm 1.14^{\mathrm{a}}$ \\
\hline
\end{tabular}

Means with different superscripts within rows differ significantly $(p<0.05)$; Gr I: Exposure of non-estrus female; Gr II: Exposure of urine of non-estrus female; Gr III: Exposure of urine of estrus female; Gr IV: Exposure of estrus female

freezability and fertility of sperm in mithun species. Through this investigation, a suitable method was identified to improve the semen production and freezability by use of biostimulation technique in adult mithun bulls which indirectly supports in semen production and freezability.

Sexual behaviour or libido, protrusion and ejaculation timein breeding bulls are partially regulated and controlled by hypothalamic-hypophyseal-gonadalaxis. Gonadotropin releasing hormone $(\mathrm{GnRH})$ released from the hypothalamus triggers the release of luteinizing hormone (LH) as well as follicle stimulating hormone (FSH), which in-turn stimulates to release of androgen, testosterone from the Leydig cells of testes to enhance the spermatogenesis (Neave, 2008; Nyby, 2008). Moreover, alteration in the episodic secretion of $\mathrm{GnRH}$ regulate the secretion of the gonadotrophins such as $\mathrm{LH}$ as well as FSH in the breeding bull and thus ultimately control the testicular function for production of androgen as well as spermatogenesis (Courot, 1978; Rodriguez and Wise, 1989). It is also reported and well documented that the frequency and amplitude of $\mathrm{LH}$ pulses has been altered with the reproductive state of the breeding males (Ellis and Desjardins, 1982) and 


\begin{tabular}{lcccc}
\hline \multicolumn{5}{l}{ Table 4: Comparison of post thaw semen quality profiles following exposure of estrus cows and its urine in mithun (Mean \pm SEM) } \\
\hline Seminal Parameters & Group I & Group II & Group III & Group IV \\
\hline Post thaw motility (\%) & $34.43 \pm 1.25^{\mathrm{b}}$ & $31.32 \pm 1.83^{\mathrm{b}}$ & $42.89 \pm 1.36^{\mathrm{a}}$ & $44.37 \pm 1.81^{\mathrm{a}}$ \\
Livability (\%) & $41.12 \pm 1.56^{\mathrm{b}}$ & $39.50 \pm 1.64^{\mathrm{b}}$ & $56.87 \pm 2.19^{\mathrm{a}}$ & $57.72 \pm 1.32^{\mathrm{a}}$ \\
Acrosomal integrity (\%) & $47.91 \pm 1.42^{\mathrm{b}}$ & $46.71 \pm 1.22^{\mathrm{b}}$ & $58.43 \pm 2.45^{\mathrm{a}}$ & $61.55 \pm 1.08^{\mathrm{a}}$ \\
Total abnormality (\%) & $27.35 \pm 1.57^{\mathrm{b}}$ & $27.48 \pm 1.31^{\mathrm{b}}$ & $19.91 \pm 1.32^{\mathrm{a}}$ & $19.18 \pm 1.24^{\mathrm{a}}$ \\
Plasma membrane integrity (\%) & $43.23 \pm 2.29^{\mathrm{b}}$ & $40.42 \pm 1.63^{\mathrm{b}}$ & $54.76 \pm 2.83^{\mathrm{a}}$ & $56.68 \pm 1.68^{\mathrm{a}}$ \\
Nuclear Integrity (\%) & $50.12 \pm 1.32^{\mathrm{b}}$ & $49.24 \pm 1.81^{\mathrm{b}}$ & $66.78 \pm 1.60^{\mathrm{a}}$ & $68.73 \pm 1.21^{\mathrm{a}}$ \\
CMPT (mm h ${ }^{-1}$ ) & $20.36 \pm 1.19^{\mathrm{c}}$ & $19.65 \pm 1.31^{\mathrm{c}}$ & $22.68 \pm 1.33^{\mathrm{b}}$ & $25.41 \pm 1.24^{\mathrm{a}}$ \\
MMP (\%) & $31.76 \pm 1.31^{\mathrm{a}}$ & $33.25 \pm 1.68^{\mathrm{a}}$ & $36.98 \pm 1.43^{\mathrm{b}}$ & $39.54 \pm 1.62^{\mathrm{c}}$ \\
\hline
\end{tabular}

Means with different superscripts within rows differ significantly $(p<0.05)$. Gr I: Exposure of non-estrus female, $\mathrm{Gr}$ II: Exposure of urine of non-estrus female, Gr III: Exposure of urine of estrus female and Gr IV: Exposure of estrus female. MMP: Mitochondrial Membrane Potential, CPMT: Cervical mucus penetration test; vanguard distance travelled by sperm in estrus mucus

Table 5: Comparison of post thaw semen motility and velocity profiles following exposure of estrus cows and its urine in mithun (Mean \pm SEM)

\begin{tabular}{lcccc}
\hline CASA parameters & Group I & Group II & Group III & Group IV \\
\hline Progressive forward motility (\%) & $16.87 \pm 1.78^{\mathrm{a}}$ & $16.43 \pm 1.74^{\mathrm{a}}$ & $29.78 \pm 1.43^{\mathrm{b}}$ & $28.33 \pm 2.23^{\mathrm{b}}$ \\
Total motility (\%) & $28.83 \pm 1.12^{\mathrm{a}}$ & $28.21 \pm 1.34^{\mathrm{a}}$ & $42.50 \pm 1.81^{\mathrm{b}}$ & $41.46 \pm 1.64^{\mathrm{b}}$ \\
Static Sperms (\%) & $71.54 \pm 2.34^{\mathrm{a}}$ & $71.13 \pm 1.53^{\mathrm{a}}$ & $57.48 \pm 1.78^{\mathrm{b}}$ & $58.73 \pm 1.76^{\mathrm{b}}$ \\
Curvilinear velocity (VCL) $\left(\mu \mathrm{m} \mathrm{sec}^{-1}\right)$ & $115.96 \pm 2.35^{\mathrm{a}}$ & $115.26 \pm 2.53^{\mathrm{a}}$ & $135.31 \pm 2.98^{\mathrm{b}}$ & $135.58 \pm 3.32^{\mathrm{b}}$ \\
Straight line velocity (VSL) $\left(\mu \mathrm{m} \mathrm{sec}^{-1}\right)$ & $78.87 \pm 2.43^{\mathrm{a}}$ & $79.34 \pm 1.76^{\mathrm{a}}$ & $101.12 \pm 2.34^{\mathrm{b}}$ & $98.72 \pm 2.63^{\mathrm{b}}$ \\
Average path velocity (VAP) ( $\left.\mu \mathrm{m} \mathrm{sec}^{-1}\right)$ & $96.43 \pm 1.32^{\mathrm{a}}$ & $95.30 \pm 2.85^{\mathrm{a}}$ & $126.83 \pm 2.14^{\mathrm{b}}$ & $119.23 \pm 2.56^{\mathrm{b}}$ \\
Linearity (LIN) (\%) & $67.73 \pm 1.56^{\mathrm{a}}$ & $65.01 \pm 1.34^{\mathrm{a}}$ & $74.76 \pm 1.72^{\mathrm{b}}$ & $73.93 \pm 1.43^{\mathrm{b}}$ \\
Straightness (STR) (\%) & $79.62 \pm 1.78^{\mathrm{a}}$ & $78.43 \pm 1.54^{\mathrm{a}}$ & $81.33 \pm 1.65^{\mathrm{b}}$ & $82.27 \pm 1.84^{\mathrm{b}}$ \\
Wobble (WOB) (\%) & $82.83 \pm 1.32^{\mathrm{a}}$ & $83.04 \pm 1.64^{\mathrm{a}}$ & $94.43 \pm 1.73^{\mathrm{b}}$ & $94.33 \pm 1.72^{\mathrm{b}}$ \\
Amplitude of lateral head displacement $(\mu \mathrm{m})$ & $1.26 \pm 0.08^{\mathrm{a}}$ & $1.32 \pm 0.23^{\mathrm{a}}$ & $3.85 \pm 0.38^{\mathrm{b}}$ & $3.71 \pm 0.49^{\mathrm{b}}$ \\
Beat/cross frequency (BCF) (Hz) & $12.39 \pm 0.78^{\mathrm{a}}$ & $12.20 \pm 0.71^{\mathrm{a}}$ & $23.56 \pm 1.12^{\mathrm{b}}$ & $22.52 \pm 1.08^{\mathrm{b}}$ \\
\hline
\end{tabular}

Means with different superscripts within rows differ significantly ( $p<0.05)$; $\mathrm{Gr}$ I: Exposure of non-estrus female; $\mathrm{Gr}$ II: Exposure of urine of non-estrus female; Gr III: Exposure of urine of estrus female; Gr IV: Exposure of estrus female

\begin{tabular}{|c|c|c|c|c|}
\hline Hormone Profiles & Group I & Group II & Group III & Group IV \\
\hline Testosterone $\left(\mathrm{ng} \mathrm{ml}^{-1}\right)$ & $2.19 \pm 0.06^{\mathrm{ab}}$ & $1.85 \pm 0.07^{\mathrm{a}}$ & $2.98 \pm 0.04^{b}$ & $3.35 \pm 0.01^{c}$ \\
\hline $\mathrm{FSH}\left(\mathrm{mIU} \mathrm{ml} \mathrm{l}^{-1}\right)$ & $3.35 \pm 0.07^{a}$ & $2.78 \pm 0.04^{\mathrm{a}}$ & $4.85 \pm 0.02^{b}$ & $5.51 \pm 0.03^{b}$ \\
\hline $\mathrm{LH}\left(\mathrm{mIU} \mathrm{m}^{-1}\right)$ & $2.63 \pm 0.05^{\mathrm{a}}$ & $2.23 \pm 0.06^{\mathrm{a}}$ & $3.86 \pm 0.07^{b}$ & $4.85 \pm 0.07^{c}$ \\
\hline
\end{tabular}

Means with different superscripts within rows differ significantly ( $p<0.05)$; Gr I: Exposure of non-estrus female; $\mathrm{Gr}$ II: Exposure of urine of non-estrus female; Gr III: Exposure of urine of estrus female; Gr IV: Exposure of estrus female

there is a close temporal inter-relationship between these two hormones in the bovine bull (McCarthy et al., 1979) which inturn increase sperm production and its freezability. Male animals release reflexively testosterone when theyare exposed to smell (anticipatory releases) or to estrus female to mate (ejaculatory release) with a novel receptive female animals (Nyby, 2008; Bonilla-Jaime et al., 2006). The variation in the semen production and freezabilityis due to variation in the endocrinological parameters in the mithun bulls,variation in the endocrinological profiles is due to neurochemical and neuroendocrine mechanisms especially the bulls are exposed to receptive estrusfemale or its secretion (Naumenko et al., 1991). Further, it was also reported that the female pheromones stimulate to increase plasma testosterone 
and other related hormones in male at distant places (Amstislavskaya et al., 2004) which inturnstimulate the semen production and higher its qualityand freezability; the intensity of enhancement is differed with breeds or strains/species (Naumenko et al., 1983). Chemical signals are believable and reliable indicators of reproductive condition of an individual because they are closely inter-related and linked to physical, physiological, endocrinological and spermatogenesis changes and are associated with reproduction and fertility of male. They are honest signals that convey the information to the receiver the reproductive state of the sender (Gittleman, 1989). These chemical signals or bio-molecules are highly species-specific and varied with species (copulin from the vagina of the rhesus monkey: Michael, 1973; valeric acid or a mixture of fatty acids produced by oestrous felids: Bland, 1979; frontalin in Asian elephants: Rasmussen and Green wood, 2003). Thus, the importance of chemical signals/biomolecules has been recognized increasingly in the field of reproductive biology and endocrinology to understand the reproductive state as well as the performance of individuals through analysis of species-specific behavioural cues (Berger, 1992). Testosterone level has increased to a maximum of 20 minute after exposure to the receptive estrusfemale and then over half an hour, it has decreased to a control level and however, the behavioural reaction started immediately and remained at a high level after an hour (Pfaus et al., 2001) whereas testosterone concentration is increased in 20-40 min after exposure of female odour which can be considered as a delayed response and response to the female odouris species-specific and innate (Naumenko et al., 1983). Therefore, the variation was observed between the estrus and non-estrus exposure in mithun. In the present study, there was variation in the semen production, its quality and freezability parameters in different experimental methods. Different semen production response in males to the presence of a receptive female and its secretion could be due to different dynamics and kinetics of blood testosterone alteration conditioned by a number of physiological mechanisms.

The pheromones available in the cows or its secretions are highly responsible to stimulate the secretion of hormones through vomeronasal organ (VNO). Human beings have a pair of VNOs in the anterior nasal septum (Garcia-Velasco and Mondragon, 1991; Stensaas et al., 1991) and it is also functional. In other mammals, stimulation of VNO with pheromones activates limbic and hypothalamic structures and results in alteration of sexual and social behaviour and modulation of neurochemical and neuroendocrine reflexes and ultimately leads to variation in the endocrinological parameters (Garcia-Velasco and Mondragon, 1991) and leads to alteration of semen production and its quality profiles and freezability. The social stimuli such as the sound, sight and smell/odour of a female in estrous can stimulate the endocrine changes in males (domestic sheep: Gonzales et al., 1988; grey lag goose: Kotrschalet al., 2000; rhesus monkeys: Bernstein et al., 1977) which inturn alter the semen production, quality profiles and freezability and similar result was observed in the present study in mithun species.

Breeding males of variety of species, including humans, have repeatedly been shown to respond to female stimuli by triggering an increase in luteinizing hormone (LH) immediately followed by a rise in plasma testosterone (Clancy et al., 1988; Roney et al., 2007) which improves the sexual libido, behaviour, semen production, freezability parameters. Similar condition was also observed in the present study that the success rate and length of penis were significantly higher and protrusion and ejaculation time were significantly lower in bulls that exposed to estrus cows or its urine than in non-estrus cows or its urine. Rapid testosterone release occurs in at least two different reproductive situations, in first, initial exposure to a female and also following ejaculation, should the interaction lead to mating; generally, hormone levels rise within 10 min of encountering a female, peak within 20-30 min and return to basal levels within $80 \mathrm{~min}$ (Richardson et al., 2004). Moreover, the female is not required to induce behavioural stimulation and urinary scent of femaleis enough to trigger an identical testosterone secretion (Maruniak and Bronson, 1976) and testosterone response is pheromonally driven (Wysocki and Bernhard, 1983; Coquelin et al., 1984). It was found that estrus female urine elicited $\mathrm{LH}$ response in sexually naive male, the response was more robust when the animals were sampled again after they became sexually experienced (Clancy et al., 1988). This result suggests that the presence of the female herself is not mandatory, as urinary pheromones alone are effective in triggering the testosterone response (Maruniak and Bronson, 1976) which inturn responsible for improvement of semen production, freezability and fertility. Breeding male also responds to urinary odours from females at any stage of the estrus cycle (Johnston and Bronson, 1982). In rats, urinary odours of females in heat are highly attractive to intact male (Clancy et al., 1988). Males prefer the urine of estrus females than that of non-estrus females (Coquelin et al., 1984). Carr et al. (1965) reported that only males with heterosexual experience prefer odours from receptive females than from odours of non-receptive females. However, when urine, faeces and vaginal discharges were exposed to the males, sexually active naive males showed a clear preference for odours from estrus females than to non-estrus females. Similar result was reported in the present study that semen production and freezability were significantly higher in bulls exposed to estrus cows or its secretion than to nonestrus cows or its secretion. Research with ovine species is in agreement that the most consistent endocrine responses to estrus cows are reported in sexually experienced mithun males (Borg et al., 1992). Although the exact mechanism is unknown, it seems likely that males with sexual experience are able to show the mating behaviour with a female 
stimulusand produce a stronger or more specific $\mathrm{LH}$ and testosterone signal. It has been reported in several studies that bulls are able to discriminate between oestrous and nonoestrous odour (Paleologou, 1977). Sankar and Archunan (2004) found that the duration of flehmen behaviour displayed by bulls was greater during exposure to oestrous samples of vaginal mucus, saliva, faeces and milk smeared on to the genital region of non-oestrous cows than exposure to samples collected during other oestrous cycle stages. Among the substances tested, the response to oestrous vaginal mucus was significantly higher than for the other substances. Klemm et al. (1987); Rivard and Klemm (1989) also presented their samples to bulls in a dish. The substances studied were vaginal mucus (Rivard and Klemm, 1989; Klemm et al., 1987), serum and vulval skin gland secretions (Rivard and Klemm, 1989). They found that all three of these body fluids from cows in oestrus evoked a series of chained behaviours, which could be divided into three categories (Rivard and Klemm, 1989). The attraction phase comprised initial responsessuch as head orientation toward the sample, sniffing the air, moving toward the sample, sniffing the sample at close range, salivation and urination. It was followed by the detection phase, which included behaviours such as licking, tongue manipulation, hyper-salivation, laboured breathing, flehmen and vocalisation. During the phase of sexual preparation, the bulls displayed penis protrusion, penile secretionand head butting and mounting behaviour. These observations were observed in the present study also. Ramesh Kumar et al. (2000) analysed urine from cows in different stages of cyclicity and found that 1-iodo undecane and di-n-propyl phthalate were unique to the oestrous samples. Further evidence that 1-iodo undecane is oestrus-specific was supported by Sankar and Archunan (2008). When they compared volatile profiles from faeces of cows in different stages of the reproductive cycle, they found three compounds, acetic acid, proprionic acid and 1-iodo undecane, that were specific for the oestrous phase. The dispersion of oestrus-specific compounds in the bovine body has been demonstrated previously in swabs from the vulva and fluids from the vagina, urine, milk and blood (Rivard and Klemm, 1989; Kiddy et al., 1984). However, in the present study, the active compounds in the urine in mithun were not estimated.

\section{Conclusion}

It was concluded from the present study that exposure of estrus females or its urine has not only improved semen production and its quality parameters but also enhanced the freezability and fertility of sperm in mithun species. Through this investigation, a suitable method was identified to improve the semen production and freezability by use of biostimulation technique in adult mithun bulls which indirectly supports in semen production and freezability.

\section{References}

Amstislavskaya, T.G., Popova, N.K., 2004. Female induced sexual arousal in male mice and rats: behavioural and testosterone response. Hormonal Behaviour 46, 544-550.

Barth, A.D., Oko, R.J., 1989. Preparation of semen for morphological examination. In: Abnormal morphology of bovine spermatozoa, lowa State University Press, Ames, IA, 8-18.

Berger, J., 1992. Facilitation of reproductive synchrony by gestation adjustment in gregarious mammals: a new hypothesis. Ecology 73, 323-329.

Bernstein, I.S., Rose, R.M., Gordon, T.P., 1977. Behavioural and hormonal responses of male rhesus monkeys introduced to females in the breeding and non-breeding seasons. Animal Behaviour 25, 609-614.

Bhattacharyya, H.K., Goswami, B.K., Bujarbaruah, K.M., Deka, B.C., Biswas, R.K., 2009. Collection and characterization of semen in mithun (Bos frontalis) bulls. Theriogenology 72, 699-703.

Bland, K.P., 1979. Tom cat odour and other pheromones in Feline reproduction. Veterinary Science Communication 3, 125-136.

Bonilla-Jaime, H., Vazquez-Palacios, G., Arteaga-Silva, M., Retana-Marquez, S., 2006. Hormonal responses to different sexually related conditions in male rats. Hormonal Behaviour 49, 376-382.

Borg, K.E., Esbenshade, K.L., Johnson, B.H., Lunstra, D.D., Ford, J.J., 1992. Effects of sexual experience, season, and mating stimuli on endocrine concentrations in the adult ram. Hormonal Behaviour 26, 87-109.

Carr, W.J., Loeb, L.S., Dissinger, M.L., 1965. Responses of rats to sex odours. Journal of Comparative Physiology and Psychology 59, 370-377.

Clancy, A.N., Singer, A.G., Macrides, F., Bronson, F.H., Agosta, W.C., 1988. Experiential and endocrine dependence of gonadotropin responses in male mice to conspecifics urine. Biology of Reproduction 38, 183-191.

Coquelin, A., Clancy, A.N., Macrides, F., Noble, E.P., Gorski, R.A., 1984. Pheromonally induced release of luteinizing hormone-releasing hormone: involvement of the vomeronasal system. Journal of Neuroscience 4, 2230-2236.

Courot, M., 1978. Prepubertal development and puberty: comparative aspects. International Journal of Andrology 1(s1), 11-20.

Ellis, G.B., Desjardins, C., 1982. Male rats secrete luteinizing hormone and testosterone episodically. Endocrinology 110(5), 1618-1627.

Garcia-Velasco, J., Mondragon, M., 1991. The incidence of the vomeronasal organ in 1000 human subjects and its possible clinical significance. Journal of Steroid Biochemistry and Molecular Biology 4B, 561-563.

Gittleman, J.L., 1989. Carnivore behavior ecology and 
evolution. Cornell University Press, New York.

Gonzales, R., Poindron, P., Signoret, J.P., 1988. Temporal variation in $\mathrm{LH}$ and testosterone responses of rams after the introduction of oestrus females during the breeding season. Journal of Reproduction and Fertility 83, 201-208.

Jeyendran, R.S., Vander Ven, H.H., Parez-Pelaez, M., Crabo, B.G., Zaneweld, L.J.D., 1984. Development of an assay to assess the functional integrity of the human membrane and its relationship to other semen characteristics. Journal of Reproduction and Fertility 70, 219-228.

Johnston, R.E., Bronson, F.H., 1982. Endocrine control of female mouse odours that elicit luteinizing hormone surges and attraction to males. Biology of Reproduction 27, 1180-1183.

Kiddy, C., Mitchell, D., Hawk, H., 1984. Estrus-related odours in body fluids of dairy cows. Journal of Dairy Science 67(2), 388-391.

Klemm, W.R., Hawkins, G.N., Delossantos, E., 1987. Identification of compounds in bovine cervico-vaginal mucus extracts that evoke male sexual behaviour. Chemical Senses 12(1), 77-87.

Kotrschal, K., Dittami, J., Hirschenhauser, K., Mostl, E., Peczely, P., 2000. Effects of physiological and social challenges in different season on faecal testosterone and corticosterone in male domestic geese (Anser domesticus). Acta Ethology 2, 115-122.

Lasley, J.F., Bogart, R., 1944. A comparative study of epididymal and ejaculated spermatozoa of boar. Journal of Animal Science 3, 360-370.

Maruniak, J.A., Bronson, F.H., 1976. Gonadotropin responses of male mice to female urine. Endocrinology 99, 936-969.

Matouseket, J., Riha, J., Sarsen, V., Veselky, H., Londa, F., 1989. Penetration of cervical mucus and other body fluids by bull sperm in capillary tubes. Animal Reproduction Science 18, 161-166.

McCarthy, N.S., Convey, E.M., Hafs, H.D., 1979. Serum hormonal changes and testicular response to $\mathrm{LH}$ during puberty in bulls. Biology of Reproduction 20, 1221-1227.

Michael, R.P., 1973. The effects of hormones on sexual behaviour in the female cat and rhesus monkey. In: Handbook of Physiology, vol. 2. American Physiological Society, 187-221.

Mondal, M., Karunakaran, M., Lee, K.B., Rajkhowa, C., 2010. Characterization of mithun (Bosfrontalis) ejaculates and fertility of cryopreserved sperm. Animal Reproduction Science 118, 210-216.

Naumenko, E.V., Amstislavskaya, T.G., Osadchuk, A.V., 1991. The role of adrenoceptors in the activation of the hypothalamic-pituitary-testicular complex of mice induced by the presence of female. Experimental Clinical Endocrinology 97(1), 1-12.

Naumenko, E.V., Osadchuk, A.V., Serova, L.I., Shishkina, G.T.,
1983. Genetic-physiological mechanisms of testicular function regulation. Novosibirsk, Nauka, 201.

Neave, N., 2008. Hormones and Behavior: a psychological approach. Cambridge University Press, Cambridge, U.K.

Nyby, J.G., 2008. Reflexive testosterone release: A model system for studying the non-genomic effects of testosterone upon male behaviour. Front Neuroendocrinology 29, 199-210.

Paleologou, A., 1977. The detection of oestrus cows for insemination by a new method based on bovine sex pheromones. Journal of Institute Animal Technicians 28(2), 97-101.

Perumal, P., Rajkhowa, C., 2013. Scrotal circumference and its relationship with testicular growth, age and semen production in mithun (Bos frontalis) bulls. Indian Journal of Animal Sciences 83(10), 1074-1077.

Perumal, P., Chamuah, J.K., Nahak, A.K., Rajkhowa, C., 2015. Effect of melatonin on the liquid storage $\left(5^{\circ} \mathrm{C}\right)$ of semen with retrospective study of calving rate at different season in mithun (Bos frontalis). Asian Pacific Journal of Reproduction 4(1), 1-12.

Perumal, P., Chang, S., Sangma, C.T.R., Khate, K., Saminathan, M., 2016. Unilateral cryptorchidism on mobility and velocity parameters in mithun sperm. Journal of Experimental Biology Agricultural Science 4(spl-3), S116-S122.

Perumal, P., Khate, K., Rajkhowa, C., 2013. Effect of foot and mouth disease vaccination on seminal and biochemical profiles of mithun (Bos frontalis) semen. Asian Pacific Journal of Reproduction 2(3), 209-214.

Perumal, P., Savino, N., Sangma, C.T.R., Chang, S., Sangtam, T.Z.T., Khan, M.H., Singh, G., Brijesh Kumar, Yadav, D., Srivastava, N., 2017. Effect of season and age on scrotal circumference, testicular parameters and endocrinological profiles in mithun bulls. Theriogenology 98, 23-29.

Perumal, P., Selvaraju, S., Selvakumar, S., Barik, A.K., Mohanty, D.N., Das, R.K., Das, S., Mishra, P.C., 2011. Effect of prefreeze addition of cysteine hydrochloride and reduced glutathione in semen of crossbred Jersey bulls on sperm parameters and conception rates. Reproduction in Domestic Animals 46(4), 636-641.

Pfaus, J.G., Kippin, T.E., Centeno, S., 2001. Conditioning and sexual behaviour: a review. Hormonal Behaviour 40(2), 291-321.

Prasad, J.K., Kumar, S., Mohan, G., Agarwal, S.K., Shankar, U., 1999. Simple modified method for cervical mucus penetration test for quality assessment of bull semen. Indian Journal of Animal Sciences 69, 103-105.

Rajoriya, J.S., Prasad, J.K., Ghosh, S.K., Perumal, P., Anuj Kumar, Kaushal, S., Singh, M., 2013. Effects of seasons on enzymatic changes and cholesterol efflux in relation to freezability in Tharparkar bull semen. Asian Pacific Journal of Reproduction 2(4), 280-288. 
Ramesh Kumar, K., Archunan, G., Jeyaraman, R., Narasimhan, S., 2000. Chemical characterization of bovine urine with special reference to oestrus. Veterinary Research Communications 24(7), 445-454.

Rasmussen, L.E.L., Greenwood, D.R., 2003. Frontalin: a chemical message of musth in Asian elephants (Elephas maximus). Chemical Senses 28, 433-446.

Richardson, H.N., Nelson, A.L., Ahmed, E.I., Parfitt, D.B., Romeo, R.D., Sisk, C.L., 2004. Female pheromones stimulate release of luteinizing hormone and testosterone without altering GnRH mRNA in adult male Syrian hamsters (Mesocricetus auratus). General Comparative Endocrinology 138, 211.

Rivard, G., Klemm, W., 1989. Two body fluids containing bovine estrous pheromone(s). Chemical Senses 14(2), 273-279.

Rodriguez, R.E., Wise, M.E., 1989. Ontogeny of pulsatile secretion of gonadotropin-releasing hormone in the bull calf during infantile and pubertal development. Endocrinology 124(1), 248-256.

Roney, J.R., Lukaszewski, A.W., Simmons, Z.L., 2007. Rapid endocrine responses of young men to social interactions with young women. Hormonal Behaviour 52, 326-333.

Salisbury, G.W., VanDemark, N.L., Lodge, J.R., 1985. Physiology of reproduction and artificial insemination of cattle. $2^{\text {nd }}$ ed. W.H. Freeman and Company, 268-274.
Sankar, R., Archunan, G., 2004. Flehmen response in bull: role of vaginal mucus and other body fluids of bovine with special reference to estrus. Behavioural Processes 67(1), 81-86.

Sankar, R., Archunan, G., 2008. Identification of putative pheromones in bovine (Bos taurus) faeces in relation to estrus detection. Animal Reproduction Science 103(1-2), 149-153.

Snedecor, G.W., Cochran, W.G., 1994. Statistical methods. $8^{\text {th }}$ ed., Ames, IOWA, USA, IOWA State University Press.

Stensaas, L.J., Lavker, R.M., Monti-Bloch, L., Grosser, B.I., Berliner, D.L., 1991. Ultrastructure of the human vomeronasal organ. Journal of Steroid. BiochemMolecular Biology 4B, 553-560.

Tomar, N.S., 1997. Artificial insemination and reproduction of cattle and buffalos. Saroj prakashan, Allahabad, India.

VanEerdenburg, F.J.C.M., Loeffler, S.H., Van Vliet, J.H., 1996. Detection of oestrus in dairy cows: a new approach to an old problem. Veterinary Quarterly 18, 52-54.

Watson, P.F.,1975. Use of Giemsa stain to detect change in acrosome of frozen ram spermatozoa. Veterinary Record 97, 12-15.

Wysocki, C.J., Bernhard, K.Y.R., 1983. Male vomeronasal organ mediates female induced testosterone surges in mice. Biology of Reproduction 28, 917-922. 